\section{Kastamonu Eğitim Dergisi Kastamonu Education Journal}

Temmuz 2019 Cilt:27 Sayı:4

kefdergi.kastamonu.edu.tr
Başvuru Tarihi/Received: 01.04.2018

Kabul Tarihi/Accepted: 31.08.2018

DOI: 10.24106/kefdergi.2928

\title{
Ortaokul Hukuk ve Adalet Dersi Öğretim Programına ílişkin Öğretmen Görüşlerinin Belirlenmesi
}

\section{Evaluation Of Secondary Elective Legal and Justice Course Teaching Program According to Teacher's Vision}

\section{Öz}

\author{
Eser İŞi' ${ }^{1}$, Ömer Faruk SÖNMEZ²
}

Hukuk ve Adalet Dersi Öğretim Programı 2013-2014 eğitim öğretim yılından itibaren ortaokul 6. ve 7. seçmeli olarak okutulan bir derstir. Öğretim programı kapsamında öğrenciler de hukuk ve adalet bilincinin geliştirilmesi, hukuk okuryazarlıklarının geliştirilmesi gibi bilgi ve becerilerin kazandırılması amaçlanmaktadır. Çalışma kapsamında Ortaokul Seçmeli Hukuk ve Adalet dersi öğretim programı öğeleri öğretmen görüşlerine göre değerlendirilmiştir. Araştırmada tarama modeli kullanılmıştr. Nitel ve nicel araştırma yöntemlerinden çalışmada yararlanılmıştr. Araştırma evrenini ülkemiz çapında hukuk ve adalet dersini okutan sosyal bilgiler öğretmenleri oluşturmaktadır. Araştırma örneklemi ülkemizde 55 ilde görev yapan 268 sosyal bilgiler öğretmeni oluşturmaktadır. Araştırma verileri araştırmacı tarafindan geliştirilen Hukuk ve Adalet Dersi Öğretim Programı Öğretmen Görüşleri Anketi ile elde edilmiştir. Ankette yer alan nicel veriler SPSS 22.0 istatistik analiz programı ile nitel maddelere ilişkin yanıtlar ise içerik analizi tema ve kategorilere ayrılarak, tablo ve grafikler haline getirilmiştir. Bu tablo ve grafikler yorumlanmıştr. Araştırma kapsamında elde edilen sonuçlara göre, sosyal bilgiler. öğretmenlerine göre hukuk ve adalet dersi öğrencilerde hukuk ve adalet bilincinin yerleşmesine katkı sağlamış, öğrencilerin kurallara uyma davranışında artış yaşanmış ve hukuksal kavramalara yönelik farkındalık artmıştı. Öğretmenlerce içeriğin ve bazı kavramların öğrenci hazırbulunuşluğuna uygun olamadığı yönünde görüşler ifade edilmiştir.

Anahtar Kelimeler: Hukuk, adalet, kural, öğretim programı

\section{Abstract}

Law and Justice Curriculum Teaching Program from the 2013-2014 education year, the 6th and 7th secondary schools are an optional course. Within the scope of the curriculum, it is aimed to gain knowledge and skills such as the development of law and justice awareness and the development of legal literacy in the students. Within the scope of the study, secondary school elective law and justice curriculum items were evaluated according to teacher opinions. The survey model was used in the study. Qualitative and quantitative research methods were utilized in the study. The social studies teachers who teach the law and justice course around the country constitute the research universe. In our research sample, 268 social studies teachers working in 55 countries constitute teachers. The research data were obtained from the Teacher Opinion Survey of Law and Justice Teaching Program developed by the researcher. The quantitative data in the questionnaire were transformed into tables and graphs by analyzing the SPSS 22.0 statistical analysis program and the responses related to qualitative items by content analysis theme and category. These tables and graphics are interpreted. According to the results obtained within the scope of the research, it was seen that the general attitude scores of the social studies teachers towards Law and Justice course were high and the attitude scores related to the content and measurement dimension were realized at the level of medium and unstable. According to the teachers, law and justice lessons contributed to the settlement of the law and justice in the students, increasing the students' behavior in compliance with the rules and increasing awareness about the legal conceptions. Teachers have expressed opinions that the content and some concepts are not appropriate for the availability of students.

Keywords: Law, justice, rule, curriculum 


\section{Extended Abstract}

Man is a natural reality as well as a social reality. It needs social connections, value judgments and patterns of behaviors that are set in social life while meeting human needs (Cansel \& Özel, 2012). Since the beginning of life as a human society, besides personal physical needs, the necessities brought about by living in society have emerged. In order to be able to respond to these societal needs, it sets and implements rules by way of value judgments. Because social relations need alignment. One of the rules governing society is the rule of law. This means that the order rules, prohibitions, leads or permits. While the rules of law provide justice, the society also meets the need for security and justice (Ildır, 2006). The law, which takes its power from the material assets of the state and the value judgments of the society, aims to provide justice with this force in its possession. In this context, law; it promotes peace in society, trust among people, equality and social freedom (Andaç, 2008). It is only through the provision of justice that the rule of law of the society is to be accepted by the society to provide and maintain the social order. The sustainability of the system of justice and law, which is a complementary whole, is possible only if it is owned by the society. The institution that will provide this is education (Gülener, 2013).

Elective Course of Law and Justice Teaching Programme which is taught at lower secondary schools of Turkey included Imam Hatip Secondary schools has been accepted by the Republic of Turkey, Ministry of National Education, Board of Education on 7/6/2013 to be implemented from 2013/2014 Academic Year (MEB, 2013 ). The main aim of the course is to develop the conscious of law in students. The purpose of this research is to determine the views of the teachers towards the curriculum of Secondary School and Imam Hatip Secondary School Elective Course of Law and Justice. In order to regulate the social relations between people, the law which is formed within the society's own dynamics and supported by the power of the state's control needs to be internalized by all the members of society. To educate people has a big part in raising the awareness of law and justice system. The establishment of social order, rights, responsibility and legal awareness at an early age through educational institutions will contribute significantly to social relations in the coming years. A large part of the task of fulfilling this function in schools falls into secondary school Elective Course of Law and Justice. Training is provided within the framework of the teaching program of this course. The relevance of the elements of the curriculum to the basic philosophy of the course is important for achieving the main objectives of the course. Teachers are practitioners of the teaching program. Therefore, the opinions of the teachers who have taught the lesson, serve for the purpose of the course, contribute to the change of the program over time and are important in terms of being able to reveal the needs related to the related field.

In this research which aims to evaluate secondary school elective law and justice curriculum according to teacher opinions, screening model is used. Quantitative and qualitative methods were used in the study together. The attitudes and opinions of the teachers about the program items in the research were examined quantitatively and the proposals related to the program and other evaluations were evaluated qualitatively. The research working group constitutes 268 Social Studies Teachers working in 55 different provinces of our country. The results obtained from teacher opinions within the scope of the research reveal that the law and justice course contributes to the settlement of the law, justice, rights and responsibility consciousness which is beneficial for the students. The Law and Justice course contributes both in terms of educational and legal system.

When theoretical and applied researches are examined, it is seen that the law and justice lessons provide students with legal and justice consciousness, that it serves for the purpose of providing social order, and that it has contents which aims to gain many important values for society.

When we look at the results obtained from the teachers' opinions within the scope of our research, we have come to the conclusion that the course raises law and justice consciousness, that there is an increase in the behaviors of complying with the law, that pupils reflect their learnings to daily life, that it is created awareness of the basic concepts related to the law and that it is effective in acquiring values in teaching programs. When the results of the research in the field and the results of our research are compared, it is seen that the results are similar and overlap each other.

The individual is intertwined with the rule case as the necessity of social life throughout its life. The individual acquires rules and order in the early ages in his family and social surroundings. The rules adopted by the family and the individual are outside the rules of law. But the teaching of the rules of the law, which provides the social order more effectively, is also important. At this point, the lessons in this area have important tasks. It is necessary for the future of the social order to gain the awareness of law and justice to the children of your future generations.

Law aims to provide order in the social relations of the individuals and to make them internalize the values like justice, equality and respect while ensuring this order. The aim of secondary school Law and Justice curriculum is to serve this most basic purpose of law. The course of law and justice aims not only to acquire legal knowledge and skills but also to ensure that these skills will be associated with everyday life and come to social order. If the individual who plays the role of the student in terms of social role can make the basic concepts and skills related to the law into a part of his life by learning in the school environment, social law and justice will become conscious and disputes in social relations will be experienced as little as possible. 


\section{Giriş}

İnsanlar yaşadıkları toplum içinde birbirleri ile çeşitli düzeylerde ilişkiler kurarlar. Doğumdan ölüme kadar bu süreç devam eder. Bu ilişkiler sürerken bireylerin istekleri, çıkarları birbirleriyle zaman zaman örtüşsmeyip çatışabilir (Anayurt, 2011).Insan doğal bir gerçeklik olmasının yanında toplumsal bir gerçekliktir. İnsan ihtiyaçlarını karşılarken toplumsal yaşam içinde kurduğu sosyal ilişkilere, değer yargılarına ve davranış kalıplarına ihtiyaç duyar (Cansel \& Özel, 2012). İnsan sahip olduğu akıl ve bilinç sayesinde toplu yaşamaya yönelmiştir (Güriz, 2003). İnsan toplum halinde yaşamaya başladığından bu yana kişisel fiziksel ihtiyaçlarının yanı sıra, toplum halinde yaşamanın beraberinde getirdiği intiyaçları da ortaya çıkmıştı. Bu toplumsal intiyaçlara cevap olabilmesi için değer yargılarından yola çıkarak kurallar koymakta ve uygulamaktadır. Çünkü toplumsal ilişkiler beraberinde düzeni gerektirir. Toplumu düzenleyen kurallardan biri de hukuk kurallarıdır. Söz konusu bu düzen kuralları, yasaklar, yol gösterir veya izin verir. Hukuk kuralları düzeni sağlarken toplumun güvenlik ve adalet intiyacını da karşılar (Ildır, 2006). Hukuk toplumsal hayatta kişilerin birbirleri ile ve toplum ile olan ilişkilerini düzenleyen ve uyulması kamunun gücü ile desteklenene sosyal kurallar bütünüdür. Toplum halinde yaşayan insanların kendilerini uymaya zorunlu olarak gördükleri kuralların başın hukuk kuralları gelmektedir (Bilge, 2010). Hukuk kuralları toplumun yaşayışını düzenlemek için devletin yetkili kurumları tarafindan konulan kurallar bütünüdür. Hukuk kurallarını hazırlayan, yürürlüğe koyan, koruyan bizzat devlettir. Bu kurallar kanun, tüzük yönetmelik gibi çeşitli isimler alırlar. Kişilerin bu kurallara uyma zorunluluğu vardır (Andaç, 2008). Hukuk kurallarının temel amacının adalet olması onu diğer sosyal düzen kurallarından ayıran yönü olmaktadır (Aral, 1985).

Gücünü devletin maddi varlığından ve toplumun değer yargılarından alan hukuk, elinde bu güçle adaleti sağlamayı amaçlar. Bu bağlamda hukuk; toplumda barışı, insanlar arası güveni, eşitliği ve toplumsal hürriyeti sağlama amacını taşır (Andaç, 2008). Hukuk kurallarının toplumsal düzeni sağlama ve bunu sürdürme görevinin toplum tarafindan kabul görmesi, ancak adaletin sağlanması ile gerçekleşebilir. Birbirini tamamlayan bir bütün olan hukuk ve adalet sisteminin sürdürülebilirliği, toplum tarafindan sahiplenilmesi ile mümkündür. Bunu sağlayacak olan kurum ise eğitimdir (Gülener, 201). Bunu sağlamak için öğretim programları içinde hukuk okuryazarlığının yer alması önem taşımaktadır.

Hukuk okuryazarlığı hukuka ait kaynakları doğru okuyabilme ve hukuk terimlerini doğru anlamaktr. Hukuk okuryazarı bir birey yaşamında hukuka ilişkin kavramlarla karşılaştı̆̆ında bunları doğru zamanda doğru yerde kullanabilmelidir. Toplum düzenini sağlayan hukuk kuralları açısından önemli olan da hukuk kurallarının hayata geçirilebilmesidir (Oğuz, 2013b). Günümüzde hukuksal okuryazarlık kavramı, hukuk sistemi ile etkili bir iletişim kurmak için gerekli tüm bilgi ve becerileri içeren bir anlama sahiptir. Başlangıçta hukuk okuryazarlığı kavramı, hukuka ilişkin mesleki eğitimin bir parçası olarak görülmüştür. Zamanla gelişen yaklaşım ise vatandaşın, modern topluma etkin katılım için belli bir derecede yasal okuryazarlığa sahip olması gerektiğini savunur (Zariski, 2014). Hukuk okuryazarlı̆̆ı, günümüz toplumlarında önem verilen bir konudur. Ortaokul yıllarında gelecekteki yaşamları için hazırlık aşamasında olan öğrencilerin asgari yasal konuların farkında olması önemlidir. Bu bilinç, öğrencilerin sorumlu vatandaşlar olmasında yardımcı olmaktadır (Patil \& Lavanya, 2012).

Ortaokul Seçmeli Hukuk ve Adalet dersine ilişkin çalışmaların başlaması, Milli Eğitim Bakanlığı ile Adalet Bakanlığı arasında 03.12.2012 tarihinde yapılan “ T.C. Adalet Bakanlığı ve T.C. Milli Eğitim Bakanlığı Öğrencilerde Hukuk Bilincinin Geliştirilmesi Uygulamaları ve Hukuk ve Adalet Dersi Öğretim Programı Geliştirmek İçin İ̧̧birliği Protokolü" isimli protokole dayanmaktadır. Söz konusu protokolün amacı, ilkokul ve ortaokul derslerinin öğretim programlarında hukuk ve adalet ile ilişkili kazanımları temel alarak, öğrencilerin temel hukuk kavramlarına ilişkin anlayışlarının ve hukuk bilincinin geliştirilmesidir. Bu kapsamda ortaokul 6. Ve 7. Sınıf öğrencileri için Hukuk ve Adalet dersi öğretim programı geliştirilmesi planlanmıştır. Protokolde; mevcut öğretim programlarında hukuk öğretim programında hukuk bilinci ile ilgili kazanımların tespit edilmesi, hukuk bilincine katkı sağlayacak kitap, afiş, broşür gibi materyallerin hazırlanması, farklı sınıf seviyeleri için kazanım önerileri geliştirilmesi kararlaştırılmıştır. Dersin öğretim programını geliştirmek üzere "Hukuk ve Adalet" dersinin çerçeve öğretim programını geliştirmek için Milli Eğitim Bakanlığı Temel Eğitim Genel Müdürlüğü ile Adalet Bakanlığı Strateji Geliştirme Başkanlığı tarafindan "Hukuk Bilinci Geliştirme Komisyonu” adıyla ortak komisyon kurulması kararlaştrılmıştır. Hukuk ve Adalet dersi içeriği ile ilgili olarak da içerikte yer verilebilecek konulara rehber teşkil etmesi için bazı önerilerde bulunulmuştur. Buna göre öğretim programında, temel hukuk kavramları, haklar ve sorumluluklar, adaletin önemi, toplumsal değişme ve adalet, hukuk ve kanunlar, yargılama süreçleri, mahkemeler başlıklarının yer alabileceği öneri olarak yer almıştır.

Ortaokul ve İmam Hatip Ortaokulu Seçmeli Hukuk ve Adalet Dersi Öğretim Programı Milli Eğitim Bakanlığı Talim ve Terbiye Kurulu Başkanlığı tarafindan 07/06/2013 tarihinde 2013-2014 Eğitim Öğretim yılından itibaren uygulanmak üzere kabul edilmiştir. Kabul edilen öğretim programı Temmuz 2013 tarihli, 2670 sayılı Tebliğler dergisinde yayınlanmıştr. Seçmeli Hukuk ve Adalet dersi için komisyon tarafindan hazırlanan ders kitabı niteliğindeki öğretim materyali, Milli 
Eğitim Bakanlığı, Talim ve Terbiye Kurulunun 09.09.2013 gün ve 2370029 sayılı kararı ile eğitim aracı olarak kabul edilmiştir. Destek Hizmetleri Genel Müdürlüğünün 06.06.2014 gün ve 2312358 sayılı yazısı ile 2014-2015 eğitim öğretim yılında kullanılmak üzere 69255 adet basılmıştır. Hukuk ve Adalet dersi ilköğretim kurumları haftalık ders çizelgesinde seçmeli ders olarak yer almıştı. Söz konusu çizelgeye göre Seçmeli Hukuk ve Adalet dersi 6. Ve7.sınıfta okutulması planlanmıştr. Hukuk ve Adalet dersini okutma görevi sosyal bilgiler öğretmenlerine verilmiştir. Milli Eğitim Bakanlığı İstatistik ve Performans Yönetimi Daire Başkanlığı verilerine göre 2016-2017 Eğitim Öğretim yılında resmi ve özel ortaokullarda seçmeli hukuk ve adalet dersini 97613 öğrenci seçmiştir (MEB, 2017).

Hukuk ve Adalet dersinin temel amacı, öğrencilerde hukuk bilincini geliştirmektir. Bu amaçla programda önce hukuk ve adaletle ilgili yeterlikler, bu yeterliklere dayalı olarak da kazanımlar belirlenmiştir.

Bu ders kapsamında öğrencilerde geliştirilmesi beklenen yeterlikler şunlardır;

- Toplumsal yaşamı düzenleyen kurallar ve bu kurallar arasında hukukun yerini kavrama,

- Hukukun temel kavramlarını anlama,

- Bir durumun hukuki bir sorun içerip içermediğini anlama,

- Hak aramanın doğal olduğunu kabul etme,

- Hakkın hukuki yollarla aranacağını kabul etme,

- Hukuki haklarını kullanmak için kimlerden ya da nerelerden yardım alacağını bilme,

- Hak arama sürecinin hukuki yollarını bilme,

- Anlaşmazlıkların barışçıl yollarla çözülebileceğini kavrama,

- Hukuki sorunların çözümünde görevli kurum ve kuruluşları tanıma,

- Yargılama sisteminin işlevini bilme

- Adaletli olmayı önemseme

Bu yeterliklerin yanında Hukuk ve Adalet dersi bazı duyarlılık ve tutumların da öğrencilerde var olmasını sağlamayı amaçlar. Öğrencilerde sorunları ele alma, hukuk bilinci kazanma, haklarını bilme ve haklara eşlik eden sorumlulukları tanıma, haklarını arama konusunda cesaret gösterme, hak arama yolları ile ne zaman ve nasıl harekete geçilmesi gerektiğini öğrenme, hakların hukukla güvence altına alındığını bilme, adalet sistemi ve uygulayıcılarını tanıma ile uzlaşma kültürünü oluşturma konularında duyarlılık geliştirmesi beklenmektedir. Gelişmesi beklenen olumlu tutumlar ise, günlük yaşamda makul olma, diğer bireylerin haklarına saygı gösterme, adil olma, adalete güvenme ve hukukun üstünlüğünü kabul etme gibi tutumlar olarak ifade edilmektedir. Bu noktada öğrencinin öğrendiği bilgiler, beceriler, tutumları günlük yaşamla ilişkilendirerek içselleştirmesine ise özel bir önem verilmektedir. (MEB, 2013).

Değer insana özgü özellikleri içine alan ve insanı diğer canlılardan ayıran temel özellikleri içinde barındıran ve insan davranışlarını şekillendiren inançlar bütünü olarak tanımlanmaktadır (Ulusoy \& Dilmaç, 2014). Demokratik toplumlar, vatandaşların toplumsal kurallara uymasını, sorumluluklarını yerine getirmesini, değerleri içselleştirmesini arzu eder. İyi bir insan olabilmek için, bireyin sorumluluklarını bilmesi ve günlük yaşantısına aktarmış olması gerekir. Bu bağlamdaki bilgi, beceri ve değerlerin edinilmesinde vatandaşlık eğitimi önemli bir paya sahiptir (Ay, 2014). Değerler eğitimi özellikle 2005 ve 2017 ylından itibaren uygulamaya konulan öğretim programlarında önemli bir yere sahip olmuştur. Bu noktada sosyal bilgiler öğretim programının değerler eğitimi açısından ayrı bir öneme sahip olmuş ve değerler eğitimi programın temel amaçlarında olmuştur. Sadece sosyal bilgiler programında değil diğer derslerde de değer eğitimi programın bir parçası olarak karşımıza çıkmaktadır. Hukuk ve Adalet dersi' de ele aldığı konular itibari ile eğitim sürecinde kazandırmak istediğimiz birçok değeri içermektedir. Çengelci (2017) tarafindan yapılan araştırmada Hukuk ve Adalet öğretim programında adalet, sorumluluk, eşitlik, saygı, cesaret, duyarlılık, barış ve uzlaşma ile güven değerlerine yer verildiği görülmüştür. Hukuk ve Adalet dersi öğretim materyalinde ise adalet, sorumluluk, güven, saygı, özgürlük, eşitlik, yardımlaşma, dayanışma, sevgi, ölçülü olma, doğal çevreye duyarlılık ile barış değerlerine yer verildiği belirlenmiştir (Çengelci Köse, 2017).

Hukuk ve Adalet dersinin ünite, yeterlik ve kazanımları Tablo 1 de yer almaktadır.

Tablo 1. Hukuk ve Adalet dersinin ünite, yeterlik ve kazanımları

\begin{tabular}{|c|c|c|c|c|}
\hline Ünite & Yeterlik (f) & $\%$ & Kazanım (f) & $\%$ \\
\hline Toplumsal Düzen ve Hukuk & 1 & 9,09 & 3 & 10 \\
\hline Hukuk ve Adalet ile İlgili Temel Kavramlar & 1 & 9,09 & 5 & 16,66 \\
\hline Adaletin Sağlanmasında Hukukun Yeri & 5 & 45,45 & 11 & 36,66 \\
\hline Anlaşmazlıkların Çözümü ve Adaletin Sağlanması İçin Çalışan Kişiler ve Kurumlar & 3 & 27,27 & 6 & 20 \\
\hline Adalet Duygusu ve Toplumsal Yaşam & 1 & 9,09 & 5 & 16,66 \\
\hline Toplam & 11 & $\% 100$ & 30 & $\% 100$ \\
\hline
\end{tabular}

| Kastamonu Eğitim Dergisi, 27(4), 2019| 


\section{Araştırmanın Amacı ve Önemi}

Bu araştırmanın amacı, Ortaokul ve İmam Hatip Ortaokulu Seçmeli Hukuk ve Adalet dersi öğretim programına yönelik öğretmen görüşlerini belirleyebilmektir. İnsanlar arası toplumsal ilişkilere düzen sağlamak için toplumun kendi dinamikleri içinde oluşan ve devletin denetleme gücü ile desteklenen hukukun, toplumun tüm bireyleri tarafindan içselleştirilmesi gerekmektedir. Söz konusu hukuk ve adalet bilincinin bireylere kazandırılmasında eğitimin önemi büyüktür. Eğitim kurumları aracılığı ile erken yaşlarda toplumsal düzen, hak, sorumluluk, hukuk bilincinin yerleşmesi gelecek yıllarda toplumsal ilişkilerde düzene önemli katkı sağlayacaktır. Okullarda bu işlevi yerine getirme görevinin büyük bir kısmı Ortaokul Seçmeli Hukuk ve Adalet dersine düşmektedir. Bu derse ait öğretim programının öğeleri çerçevesinde eğitim verilmektedir. Öğretim programının öğelerinin dersin temel felsefesine uygunluğu, dersin temel amaçlarına ulaşmak için önem taşımaktadır. Öğretim programının uygulayıcısı öğretmenlerdir. Dolayısıyla dersi okutan öğretmenlerin görüşleri, dersin amacına hizmet etmesi, programın zaman içinde değişimine katkı sağlaması, ilgili alanla ilgili ihtiyaçları ortaya koyabilmek açısından önem taşımaktadır.

\section{Araştırmanın Problemi}

Ortaokul ve İmam Hatip Ortaokulu Seçmeli Hukuk ve Adalet dersi öğretim programına yönelik öğretmen görüşlerini belirleyebilmek amacıyla aşağıdaki sorulara yanıt aranmıştır.

Araştırmanın alt amaçları maddeler halinde aşağıda yer almaktadır

- Sosyal Bilgiler Öğretmenlerinin Hukuk ve Adalet dersi öğretim programı öğelerine ilişkin görüşleri nelerdir ?

- Sosyal Bilgiler Öğretmenlerinin Hukuk ve Adalet dersi kazanımlarının yeterliliği ile ilgili görüşleri nelerdir?

- Sosyal Bilgiler Öğretmenlerinin Hukuk ve Adalet dersi Öğretim materyaline (ders kitabı) yönelik görüşleri nelerdir?

- Sosyal Bilgiler Öğretmenlerinin Hukuk ve Adalet dersinin öğrencilere katkıları ile ilgili görüşleri nelerdir?

- Sosyal Bilgiler Öğretmenlerinin Hukuk ve Adalet dersi ile ilgili yaşadıkları sorunlar ve çözüm önerileri nelerdir?

\section{Yöntem}

\section{Araştırma Modeli}

Ortaokul Seçmeli Hukuk ve Adalet dersi öğretim programının öğretmen görüşlerine göre değerlendirilmesini amaçlayan bu araştırmada tarama modeli kullanıımıştr. Tarama modeli geçmişte veya şu an halen var olan durumun olduğu gibi betimlendiği, araştırmanın konusu olan olay, birey veya nesnelerin aynen kendi koşullarında olduğu gibi betimlendiği araştırmalardır (Karasar, 2014). Bir grubun belirli özelliklerini ortaya koymak için veri toplamayı amaçlayan araştırmalara, tarama araştırması adı verilir (Büyüköztürk, Kılıç Çakmak, Akgün, Karadeniz, \& Demirel, 2012). Araştırmada nicel ve nitel yöntem bir arada kullanılmıştr. Nicel araştırma, araştırmacı rolü olarak olay ve olguların dışında, tarafsız ve nesnel olarak verinin sayısal ifadelerle araştırma sonuçlarını genelleme yapma, nitel araştırma yöntemi de öznel bakış açısı ile verinin derinliği ve zenginliği içinde betimlenmesine olanak sağlamaktadır (Yıldırım \& Şimşek, 2013). Araştırmada öğretmenlerin program öğelerine ilişkin görüşleri nicel yöntem ile programa ilişkin öneri ve diğer görüşleri nitel yöntem ile incelenmiştir.

\section{Çalışma Grubu}

Araştırma evrenini, 2014-2015, 2015-2016 ve 2016-2017 eğitim öğretim yıllarında ülkemizde görev yapan Ortaokul Seçmeli Hukuk ve Adalet dersini okutan Sosyal Bilgiler Öğretmenleri oluşturmaktadır.

Araştirmada örnekleme yöntemi olarak Seçkisiz Örnekleme yöntemlerinden Basit Seçkisiz Örnekleme Yöntemi kullanılmıştr. Araştırma çalışma grubunu, ülkemizin 55 farklı ilinde görev yapan 268 Sosyal Bilgiler Öğretmeni oluşturmaktadır.

\section{Veri Toplama Aracı}

Araştırmada veri toplama aracı olarak "Hukuk ve Adalet Dersi Öğretim Programı Öğretmen Görüşleri Anketi" kullanılmıştr. Anket maddeleri ilgili literatür taranarak ve Ortaokul ve İmam Hatip Ortaokulu Seçmeli Hukuk ve Adalet dersi öğretim programı öğeleri incelenerek oluşturulmuştur. Anket 3 bölümden oluşmaktadır. Birinci bölüm katlımcıların demografik bilgilerini ve değişkenleri içermektedir. İkinci bölüm araştırmanın nicel boyutunu oluşturan 41 maddeli derecelemeli anketi içermektedir. Üçüncü bölümde, araştırmanın nitel boyutunu oluşturan 4 açık uçlu soru yer almaktadır. Anketin nitel ve nicel boyutuna ilişkin anket maddeleri oluşturulurken uzman görüşüne başvurulmuştur. Anket 
maddeleri ile ilgili olarak, 3 alan uzmanı öğretim üyesinden ve 1 dil uzmanı öğretim üyesinden görüş alınarak, düzeltmeler yapılmıştır.

\section{Verilerin Analizi}

Araştirmada elde edilen veriler SPSS (Statistical Package for Social Sciences) for Windows 22.0 programı kullanılarak analiz edilmiştir. Verilerin değerlendirilmesinde tanımlayıcı istatistiksel yöntemleri olarak sayı, yüzde, ortalama, standart sapma kullanılmıştr. Araştırmanın nitel boyutuna ilişkin açık uçlu sorulardan elde edilen veriler nitel araştırma yöntemlerinden içerik analizi ile değerlendirilmiştir. Nitel verilerin analizinde toplanan veriler azaltılıp, kodlara ayrılmış, kodlardan hareketle kategoriler oluşturulmuştur. Söz konusu kategoriler de temaların belirlenmesinde kullanılmıştr. Kodlama, kategorilere ayırma ve tema belirleme işlemlerinin güvenirliğini sağlamak için 1 alan uzmanın görüşü alınmıştır.

\section{Bulgular}

Bu bölümde, araştrrma probleminin çözümü için, araşttrmaya katılan öğretmenlerden Ortaokul Seçmeli Hukuk ve Adalet dersi Öğretim Programı Öğretmen Görüşleri Anketi yoluyla toplanan verilerin analizi ve sonucunda elde edilen bulgular yer almaktadır. Elde edilen bulgulara dayalı olarak açıklama ve yorumlar yapılmıştır.

\section{Hukuk ve Adalet Dersi Programına Yönelik Görüşleri Anketine ilişkin Bulgular}

Araştırmaya katılan öğretmenlerin hukuk ve adalet dersi ile ilgili ifadelere verdiği cevapların dağılımları Tablo 2,3,4,3,5,6'da yer almaktadır

Katılımcıların Hukuk ve Adalet dersi öğretim programının kazanımlarına yönelik maddelere verdikleri yanıtlara ilişkin dağılımlar Tablo 2'de yer almaktadır.

Tablo 2. Öğretmenlerin Hukuk ve Adalet Dersi Kazanımları Ile İlgili ifadelere Verdiği Cevapların Dağılımları

\begin{tabular}{|c|c|c|c|c|c|c|c|c|c|c|c|c|}
\hline & & & & 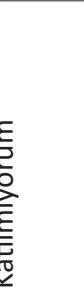 & & $\frac{\bar{c}}{\frac{1}{0}}$ & & & & 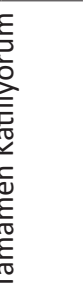 & & \\
\hline & $f$ & $\%$ & $f$ & $\%$ & $f$ & $\%$ & $f$ & $\%$ & $f$ & $\%$ & Ort & Ss \\
\hline $\begin{array}{l}\text { 1. Kazanımlar Programın Temel Amaçlarını Oluşturan Yeterlilik- } \\
\text { lere Ulaşmak İçin Uygundur }\end{array}$ & 6 & 2,2 & 23 & 8,6 & 88 & 32,8 & 117 & 43,7 & 34 & 12,7 & 3,560 & 0,900 \\
\hline 2. Kazanımlar Toplumun intiyaçlarını Karşılamaktadır & 10 & 3,7 & 30 & 11,2 & 90 & 33,6 & 111 & 41,4 & 27 & 10,1 & 3,429 & 0,947 \\
\hline 3. Kazanımlar Öğrencinin İhtiyaçlarına Cevap Vermektedir & 12 & 4,5 & 34 & 12,7 & 75 & 28,0 & 119 & 44,4 & 28 & 10,4 & 3,437 & 0,990 \\
\hline 4. Kazanımlar Öğrenciyi Hayata Hazırlayacak Niteliktedir & 14 & 5,2 & 30 & 11,2 & 71 & 26,5 & 125 & 46,6 & 28 & 10,4 & 3,459 & 0,999 \\
\hline $\begin{array}{l}\text { 5. Kazanımlar Öğrencilerin Hazırbulunuşluk Seviyesine Uygun- } \\
\text { dur }\end{array}$ & 26 & 9,7 & 58 & 21,6 & 78 & 29,1 & 84 & 31,3 & 22 & 8,2 & 3,067 & 1,116 \\
\hline 6. Kazanımlar Kendi İçinde Birbirleri ile Tutarlıdır & 10 & 3,7 & 7 & 2,6 & 74 & 27,6 & 143 & 53,4 & 34 & 12,7 & 3,687 & 0,865 \\
\hline 7. Kazanımlar Ölçülebilir, Değerlendirilebilir Niteliktedir & 6 & 2,2 & 24 & 9,0 & 80 & 29,9 & 128 & 47,8 & 30 & 11,2 & 3,567 & 0,886 \\
\hline 8. Kazanımlar Hukuk Ve Adalet Bilinci Oluşturacak Niteliktedir & 6 & 2,2 & 32 & 11,9 & 73 & 27,2 & 119 & 44,4 & 38 & 14,2 & 3,563 & 0,952 \\
\hline $\begin{array}{l}\text { 9. Kazanım İfadeleri Öğretmenlerin Yorumlama Hatası Yapmala- } \\
\text { rına Engel Olacak Şekilde Açık Ve Net Ifade Edilmiştir }\end{array}$ & 19 & 7,1 & 28 & 10,4 & 69 & 25,7 & 112 & 41,8 & 40 & 14,9 & 3,470 & 1,089 \\
\hline
\end{tabular}

Katılımcıların Hukuk ve Adalet dersi öğretim programının kazanımlarına yönelik maddelere verdikleri yanıtlara ilişkin dağılımlar Tablo 3'de yer almaktadır. 
Tablo 3. Öğretmenlerin Hukuk ve Adalet Dersi İçeriği ile ilgili ifadelere Verdiği Cevapların Dağılımları

\begin{tabular}{|c|c|c|c|c|c|c|c|c|c|c|c|c|}
\hline & & 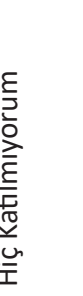 & & 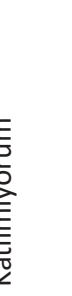 & & $\frac{E}{\frac{E}{N}} \frac{\sqrt{5}}{\frac{1}{\pi}}$ & & 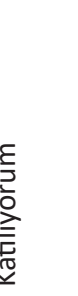 & & 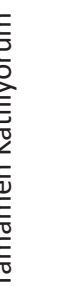 & & \\
\hline & $f$ & $\%$ & $f$ & $\%$ & $f$ & $\%$ & $f$ & $\%$ & $f$ & $\%$ & Ort & Ss \\
\hline $\begin{array}{l}\text { 10. İçerik Hukuk Ve Adalet Dersinin Kazanımlarını Gerçekleştirmek } \\
\text { İçin Uygun Ve Yeterlidir }\end{array}$ & 19 & 7,1 & 39 & 14,6 & 84 & 31,3 & 96 & 35,8 & 30 & 11,2 & 3,295 & 1,074 \\
\hline 11. Konular Toplumun İhtiyaçlarına Hizmet Edecek Niteliktedir & 17 & 6,3 & 35 & 13,1 & 79 & 29,5 & 108 & 40,3 & 29 & 10,8 & 3,362 & 1,046 \\
\hline $\begin{array}{l}\text { 12. Dersin İçeriği Öğrenme, Öğretme illkelerine (kolaydan Zora, Ya- } \\
\text { kından Uzağa, Somuttan Soyuta Vb.) Uygun Olarak Hazırlanmıştır }\end{array}$ & 14 & 5,2 & 42 & 15,7 & 60 & 22,4 & 132 & 49,3 & 20 & 7,5 & 3,381 & 1,008 \\
\hline 13. İçerik 6.sınıf Seviyesine Uygundur & 32 & 11,9 & 43 & 16,0 & 91 & 34,0 & 82 & 30,6 & 20 & 7,5 & 3,056 & 1,115 \\
\hline 14. İçerik 7.sınıf Seviyesine Uygundur & 12 & 4,5 & 24 & 9,0 & 80 & 29,9 & 118 & 44,0 & 34 & 12,7 & 3,515 & 0,977 \\
\hline $\begin{array}{l}\text { 15. İçerik Öğrencilerin Günlük Yaşamda Kullanabileceği Bilgileri } \\
\text { İçermektedir }\end{array}$ & 8 & 3,0 & 26 & 9,7 & 66 & 24,6 & 129 & 48,1 & 39 & 14,6 & 3,616 & 0,951 \\
\hline 16. Üniteler Birbiriyle İlişkilidir & 12 & 4,5 & 14 & 5,2 & 49 & 18,3 & 144 & 53,7 & 49 & 18,3 & 3,761 & 0,961 \\
\hline $\begin{array}{l}\text { 17. Konular, Adil Olma Değerinin Kazandırılmasında Etkili Olabile- } \\
\text { cek Niteliktedir }\end{array}$ & 12 & 4,5 & 22 & 8,2 & 70 & 26,1 & 114 & 42,5 & 50 & 18,7 & 3,627 & 1,022 \\
\hline 18. Konular, Önemli Ve Güncel Bilgileri İçermektedir & 14 & 5,2 & 30 & 11,2 & 74 & 27,6 & 112 & 41,8 & 38 & 14,2 & 3,485 & 1,037 \\
\hline $\begin{array}{l}\text { 19. İçerik Öğrencilerin Hukuk Ve Adalet Kavramları Konusunda Bir } \\
\text { Farkındalık Oluşturacak Kadar Kavram Bilgisine Sahip Olmasını Sağ- } \\
\text { layacak Niteliktedir }\end{array}$ & 8 & 3,0 & 37 & 13,8 & 67 & 25,0 & 105 & 39,2 & 51 & 19,0 & 3,575 & 1,041 \\
\hline $\begin{array}{l}\text { 20. Konulardaki Hukuki Terimlerin Çokluğu Öğrencilerin Öğrenme- } \\
\text { sini Zorlaştırmaktadır }\end{array}$ & 46 & 17,2 & 82 & 30,6 & 86 & 32,1 & 38 & 14,2 & 16 & 6,0 & 2,612 & 1,108 \\
\hline
\end{tabular}

Kathlımcıların Hukuk ve Adalet dersi öğretim programının öğrenme öğretme sürecine yönelik maddelere verdikleri yanıtlara ilişkin dağılımlar Tablo 4'de yer almaktadır.

Tablo 4. Öğretmenlerin Hukuk ve Adalet Dersi Öğrenme Öğretme Süreci İle İlgili İfadelere Verdiği Cevapların Dağılımları

\begin{tabular}{|c|c|c|c|c|c|c|c|c|c|c|c|c|}
\hline & & 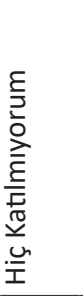 & & 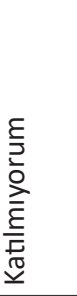 & & 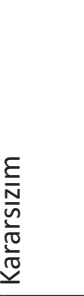 & & 点 & & 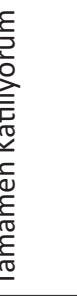 & & \\
\hline & $\mathrm{f}$ & $\%$ & $\mathrm{f}$ & $\%$ & f & $\%$ & $\mathrm{f}$ & $\%$ & $\mathrm{f}$ & $\%$ & Ort & Ss \\
\hline $\begin{array}{l}\text { 21. Program, Derste Farklı Öğretim Yöntem Ve Tekniklerini Kullanmaya } \\
\text { Imkân Vermektedir }\end{array}$ & 12 & 4,5 & 37 & 13,8 & 87 & 32,5 & 102 & 38,1 & 30 & 11,2 & 3,377 & 1,004 \\
\hline 22. Hukuk Ve Adalet Dersine Ayrılan Ders Saati Yeterlidir & 32 & 11,9 & 48 & 17,9 & 57 & 21,3 & 85 & 31,7 & 46 & 17,2 & 3,243 & 1,268 \\
\hline $\begin{array}{l}\text { 23. Öğretmen Kılavuz Kitabı Olmaması Öğretmenler Açısından Bir So- } \\
\text { rundur }\end{array}$ & 18 & 6,7 & 22 & 8,2 & 43 & 16,0 & 68 & 25,4 & 117 & 43,7 & 3,910 & 1,236 \\
\hline $\begin{array}{l}\text { 24. Programda Önerilen Yöntemler Amaçları Gerçekleştirmeye Yardım- } \\
\text { cı Olacak Niteliktedir }\end{array}$ & 12 & 4,5 & 42 & 15,7 & 85 & 31,7 & 110 & 41,0 & 19 & 7,1 & 3,306 & 0,969 \\
\hline $\begin{array}{l}\text { 25. Hukuk Ve Adalet Dersi Öğrenciyi Öğrenme Sürecinde Aktif Kılacak } \\
\text { Şekilde Organize Edilmiştir }\end{array}$ & 24 & 9,0 & 40 & 14,9 & 104 & 38,8 & 80 & 29,9 & 20 & 7,5 & 3,119 & 1,046 \\
\hline $\begin{array}{l}\text { 26. Konu Ve ünite Sonlarında Yer Alan Etkinlikler Ders Sürecinde Etkin } \\
\text { Olarak Kullanılabilmektedir }\end{array}$ & 12 & 4,5 & 35 & 13,1 & 79 & 29,5 & 118 & 44,0 & 24 & 9,0 & 3,399 & 0,976 \\
\hline $\begin{array}{l}\text { 27. Öğretim Sürecinde Öğrencilerin Merak Ve İlgi Seviyesi üst Düzey- } \\
\text { dedir }\end{array}$ & 17 & 6,3 & 36 & 13,4 & 85 & 31,7 & 94 & 35,1 & 36 & 13,4 & 3,358 & 1,073 \\
\hline $\begin{array}{l}\text { 28. Öğretim Sürecinde Yargı Kurumlarına Yönelik Olarak Ziyaretler Ya- } \\
\text { pılabilmektedir }\end{array}$ & 56 & 20,9 & 54 & 20,1 & 75 & 28,0 & 61 & 22,8 & 22 & 8,2 & 2,772 & 1,244 \\
\hline $\begin{array}{l}\text { 29. Dersin Okutulduğu Her Sınıf Seviyesi İçin Aynı Program Ve Kitabın } \\
\text { Kullanılması Öğretim Sürecini Zorlaştırmaktadır }\end{array}$ & 74 & 27,6 & 74 & 27,6 & 74 & 27,6 & 30 & 11,2 & 16 & 6,0 & 2,403 & 1,175 \\
\hline
\end{tabular}


Katılımcıların Hukuk ve Adalet dersi öğretim programının Ölçme Değerlendirme Süreci İle İlgili maddelere verdikleri yanıtlara ilişkin dağılımlar Tablo 5'de yer almaktadır.

Tablo 5. Öğretmenlerin Hukuk ve Adalet Dersi Ölçme Değerlendirme Süreci İle İlgili îfadelere Verdiği Cevapların Dağılımları

\begin{tabular}{|c|c|c|c|c|c|c|c|c|c|c|c|c|}
\hline & & 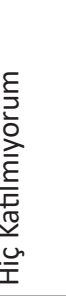 & & 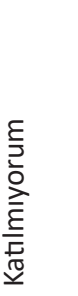 & & 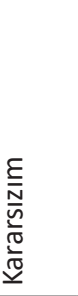 & & 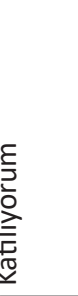 & & 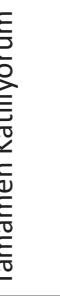 & & \\
\hline & $f$ & $\%$ & $f$ & $\%$ & $f$ & $\%$ & $f$ & $\%$ & $f$ & $\%$ & Ort & Ss \\
\hline $\begin{array}{l}\text { 30. Programın Değerlendirme Yaklaşımı Süreç Odaklı Çağdaş Ölçme Değer- } \\
\text { lendirme Yaklaşımına Uygundur }\end{array}$ & 12 & 4,5 & 34 & 12,7 & 85 & 31,7 & 121 & 45,1 & 16 & 6,0 & 3,354 & 0,935 \\
\hline $\begin{array}{l}\text { 31. Programda Ölçme Ve Değerlendirme Boyutu İle İlgili Açılamalar Yeter- } \\
\text { lidir }\end{array}$ & 10 & 3,7 & 61 & 22,8 & 71 & 26,5 & 103 & 38,4 & 23 & 8,6 & 3,254 & 1,022 \\
\hline $\begin{array}{l}\text { 32. Öğretim Materyalindeki(ders Kitabı) Etkinlikler Öğrencinin Bilgiyi Nasıl Ya- } \\
\text { pılandırdığını Ve üst Zihinsel Becerileri Ne Kadar Geliştirdiğini İyi Bir Şekilde } \\
\text { Değerlendirmemizi Sağlar }\end{array}$ & 18 & 6,7 & 50 & 18,7 & 80 & 29,9 & 102 & 38,1 & 18 & 6,7 & 3,194 & 1,035 \\
\hline $\begin{array}{l}\text { 33. Etkinliklerde Ve Ders Kitabındaki Ölçme Değerlendirme Araçlarında Ezbe- } \\
\text { re Dayalı Sorulardan Ziyade Analiz Ve Senteze Dayalı Sorular Bulunmaktadır }\end{array}$ & 18 & 6,7 & 45 & 16,8 & 77 & 28,7 & 107 & 39,9 & 21 & 7,8 & 3,254 & 1,044 \\
\hline $\begin{array}{l}\text { 34. Öğrenim Süresi İçinde Ve Sonunda Yapılan Ölçme Değerlendirme Sonra- } \\
\text { sında Kazanımların Gerçekleştiği Görülebilmektedir }\end{array}$ & 15 & 5,6 & 29 & 10,8 & 80 & 29,9 & 119 & 44,4 & 25 & 9,3 & 3,410 & 0,992 \\
\hline
\end{tabular}

Katılımcıların Hukuk ve Adalet dersi öğretim programının genel özelliklerine yönelik maddelere verdikleri yanıtlara ilişkin dağılımlar Tablo 6'da yer almaktadır.

Tablo 6. Öğretmenlerin Hukuk ve Adalet Dersi Genel Özellikleri İle İlgili İfadelere Verdiği Cevapların Dağılımları

\begin{tabular}{|c|c|c|c|c|c|c|c|c|c|c|c|c|}
\hline & & 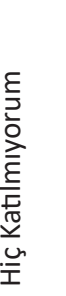 & & 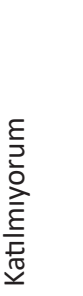 & & 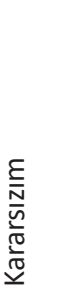 & & 点 & & 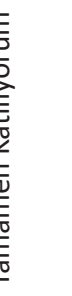 & & \\
\hline & f & $\%$ & f & $\%$ & $f$ & $\%$ & $f$ & $\%$ & $f$ & $\%$ & Ort & Ss \\
\hline 35. Dersin Kazanımları Ve İçeriği Arasında Bir Tutarlılık Vardır & 10 & 3,7 & 22 & 8,2 & 61 & 22,8 & 130 & 48,5 & 45 & 16,8 & 3,664 & 0,975 \\
\hline $\begin{array}{l}\text { 36. Hukuk Ve Adalet Dersi Okullarda Her Dönem Seçilmesi Gereken Bir } \\
\text { Derstir }\end{array}$ & 12 & 4,5 & 14 & 5,2 & 53 & 19,8 & 88 & 32,8 & 101 & 37,7 & 3,940 & 1,090 \\
\hline $\begin{array}{l}\text { 37. Program Öğretmene Rehberlik Etmekte Ve Kolaylıkla Anlaşılabilmek- } \\
\text { tedir }\end{array}$ & 14 & 5,2 & 39 & 14,6 & 80 & 29,9 & 101 & 37,7 & 34 & 12,7 & 3,381 & 1,048 \\
\hline $\begin{array}{l}\text { 38. Dersi Alan Öğrenciler Kurallara Uymaya, Sorumluluklarını Yerine Ge- } \\
\text { tirmeye Özen Göstermektedir }\end{array}$ & 12 & 4,5 & 38 & 14,2 & 71 & 26,5 & 109 & 40,7 & 38 & 14,2 & 3,459 & 1,043 \\
\hline $\begin{array}{l}\text { 39. Ders Kitabı Programda Belirlenen Yeterlilikleri Kazandırma Noktasında } \\
\text { Yeterlidir }\end{array}$ & 22 & 8,2 & 56 & 20,9 & 77 & 28,7 & 92 & 34,3 & 21 & 7,8 & 3,127 & 1,087 \\
\hline $\begin{array}{l}\text { 40. Hukuk Ve Adalet Dersi Öğretim Programı Öğrencilerde Hukuk Ve Ada- } \\
\text { let Bilinci Oluşmasında Etkilidir }\end{array}$ & 10 & 3,7 & 28 & 10,4 & 54 & 20,1 & 114 & 42,5 & 62 & 23,1 & 3,709 & 1,052 \\
\hline 41. Hukuk Ve Adalet Dersi İle İlgili Hizmet İçi Eğitime İhtiyaç Vardır & 16 & 6,0 & 29 & 10,8 & 59 & 22,0 & 98 & 36,6 & 66 & 24,6 & 3,631 & 1,142 \\
\hline
\end{tabular}

Araştrrmaya katılan öğretmenler, kazanımların ve içeriği ile ilgili anket maddelerine genel olarak olumlu yönde görüşler belirtmişlerdir. Öğrenme öğretme süreci ve programın ölçme ve değerlendirme boyutuna ilişkin anket maddeleri ile ilgili olarak kararsızlık yönünde yanıtlar vermişlerdir. Programın genel özellikleri olumlu bulunurken, aynı şekilde Hukuk ve Adalet dersi öğretim programı öğeleri ile ilgili maddelere olumlu yönde yanıtlar verilmiştir.

\section{Katılımcıların Hukuk ve Adalet Dersi Programına Konu ve Kazanım Önerilerine İlişsin Bulgular}

Katılımcı öğretmenlerin hukuk ve adalet dersi programına eklenebilecek konu ve kazanım önerilerine ilişkin cevapları tablo 7'te yer almaktadır. 
Tablo 7. Kattlımcı Öğretmenlerin Hukuk ve Adalet Dersi Programına Konu ve Kazanım Önerileri

\begin{tabular}{|c|c|c|}
\hline Temalar & Kategoriler & f \\
\hline Kavramlar & Öğrencilerin ihtiyaç duyacağı insan hakları ve adaletle ilgili kavramların eklenmesi gerekmektedir. & 4 \\
\hline$(f=8)$ & $\begin{array}{l}\text { Programda var olan anayasa, çocuk hakları gibi bazı kavram ve kazanımların daha açıklayıcı olması } \\
\text { gerekli. }\end{array}$ & 4 \\
\hline Değerler & İnsani evrensel değerlere yer verilmelidir. & 3 \\
\hline$(f=4)$ & Demokrasi bilinci de hukuk bilinci gibi önemlidir. & 1 \\
\hline Günlük Yaşantı ile & Kazanımlar günlük yaşamda uygulamaya dönük olmalı & 7 \\
\hline bağlant & Adaletin topluma faydaları, hak hukuk bilinci çerçevesinde verilmeli. & 4 \\
\hline & Tarihten örneklere yer verilmelidir. & 4 \\
\hline$(f=18)$ & Okul kurallarına ilişkin bilgilere yer verilmeli. & 3 \\
\hline Yeterli & Mevcut kazanımların yeterli olduğunu düşünüyorum. & 4 \\
\hline$(f=6)$ & Yeterli ancak Öğrenci seviyesine uygun olması gerekli. & 2 \\
\hline & Toplam & 36 \\
\hline
\end{tabular}

Tablo 7 incelendiğinde Hukuk ve Adalet dersi öğretim programına eklenebilecek konularla ilgili soruya 36 katlımcının cevap verdiği görülmektedir. Araştırmaya katılan öğretmenlerin büyük bir kısmı "Günlük Yaşamla Bağlant" teması kapsamında öneride bulunmuşlardır ( $f=18$. Bunun yanında "Kavramlar" $(f=8)$, "Değerler" $(f=4)$ temalarında da eklemeler yapılabileceği öğretmenler tarafinda ifade edilmiştir. Araştırmaya katılan $(f=6)$ öğretmen ise mevcut konu ve kazanımların yeterli olduğunu ifade etmişlerdir.

Araştırmaya katılan öğretmenlerden "Günlük Yaşamla Bağlant" teması kapsamında öneride bulunanlar; kazanımların günlük yaşama dönük olması gerektiğini $(f=7)$, adaletin topluma etkilerine yer verilmesi gerektiğini $(f=4)$ ve okul kurallarına ilişkin bilgilerinde verilmesini gerektiğini $(f=3)$ tarihimizden örnekler verilmesi gerektiğini $(f=4)$ ifade etmişlerdir.

\section{Öğretim Materyaline (Ders Kitabı) Yönelik Öğretmen Görüşlerine ilişsin Bulgular}

Katılımcı öğretmenlerin Hukuk ve Adalet dersi öğretim materyaline ilişkin bulgular tablo 8'te yer almaktadır.

\section{Tablo 8. Katılımcı Öğretmenlerin Öğretim Materyaline (Ders Kitabı) ilişkin Görüşleri}

\begin{tabular}{llc}
\hline Temalar & Kategoriler & \\
\hline & Ders kitabında yer alan etkinlikler öğrenciyi aktif kılacak etkinlikler olmalı çeşidi ve sayısı artmalı. & 13 \\
Öneri & Ders kitabı görseller, karikatürler açısından daha da zenginleşmeli & 10 \\
$(\mathrm{f}=37)$ & Ders kitabı içeriği sade ve öğrenci seviyesine uygun olmalıdır & 8 \\
& Kitapta günlük hayatla ilişkilendirmeye yönelik örnekler yer almalıdır & \\
& İçerik güncellenmiş olmalı & 2 \\
\hline Yeterli & Ders materyalinin mevcut halini yeterli buluyorum & \\
$(\mathrm{f}=31)$ & Tasarım, görseller ve özellikle karikatürler açısın güzel hazırlanmış & 7 \\
\hline Yetersiz & Ders kitabı mevcut hali ile yetersiz kalmaktadır. & 16 \\
$(\mathrm{f}=: 23)$ & İçeriğin bazı noktaları soyut kalıyor ve öğrenci seviyesi üstü & 7 \\
\hline Geliştirilebilir & Tamamen yeterlidir diyemeyiz, geliştirilme ihtiyacı var. \\
$(\mathrm{f}=14)$ & & 14 \\
\hline
\end{tabular}

Tablo 8 incelendiğinde "Ders materyalini (ders kitabı) içerik, etkinlikler görsel tasarım vb. gibi özellikler yönünden nasıl değerlendirirsiniz?" sorusuna 105 öğretmenin yanıt verdiği görülmektedir. Araştrrmaya kattlan öğretmenler öğretim materyaline yönelik öneriler geliştirmiş $(f=35)$, öğretim materyalini yeterli $(f=31)$, yetersiz $(f=23)$ ve geliştirilebilir $(f=14)$ olarak değerlendirmişlerdir.

Araştırmaya katılan öğretmenler "Öneri" teması bağlamında, ders kitabında yer alan etkinliklerin sayısı ve çeşidi artarak öğrenciyi aktif kılacak nitelikte olması gerektiğini $(f=13)$, ders kitabının görsel açıdan zenginleştirilmesi gerektiğini $(f=10)$, ders kitabının sade ve anlaşılır olması gerektiğini $(f=8)$, kitapta günlük hayatla ilişkilendirmeye önem verilmesi gerektiğini $(f=4)$ ve içeriğin güncellenmiş olması gerektiğini $(f=2)$ ifade etmişlerdir. 
Hukuk ve Adalet Dersinin Öğrencilere Katkısına Yönelik Öğretmen Görüşlerine iliş̧in Bulgular

Katılımcı öğretmenlerin hukuk ve adalet dersinin öğrencilere katkılarına yönelik ifadeleri tablo 9'te yer almaktadır.

Tablo 9. Hukuk ve Adalet Dersinin Öğrencilere Katkısına Yönelik Öğretmen Görüşleri

\begin{tabular}{llc}
\hline Tema & Kategori & $f$ \\
\hline \multirow{3}{*}{ Bilinç ve Farkındalık (f=37) } & Öğrencilerde hukuk ve adalet bilinci gelişimine katkı sağlamıştır & 14 \\
& Öğrencilerin hak ve sorumluluklarını bilmesinde etkili olmuştur & 13 \\
& Genel bir duyarlılık ve farkındalık sağlamıştır & 10 \\
\hline \multirow{3}{*}{ Sosyal Beceriler ( $f=33)$} & Günlük hayatta kullanabilecekleri bilgileri edindiler & 18 \\
& Kurallara uyma davranışında olumlu gelişmeler sağlandı & 10 \\
& Etkin vatandaşlık becerileri kazandılar & 5 \\
\hline Katkısı Yok (f=10) & Bir katkısı olmamıştır & 10 \\
\hline \multirow{2}{*}{ Kavramlar ve Değerler (f=20) } & Hukukla ilgili temel kavramları̈ öğrendiler & 11 \\
& Değerleri tanıyıp içselleştirmelerine katkı sağladı & 9 \\
\hline Sistemi Tanıma $(f=7)$ & Yargılama sisteminin işleyişi ve adalet sistemindeki görevlileri tanıdılar & 7 \\
\hline & Toplam & 107 \\
\hline
\end{tabular}

Tablo 9 incelendiğinde Hukuk ve Adalet dersinin öğrencilere katkısına yönelik olarak 107 öğretmenin görüş belirttiği görülmektedir. Katılımcıların görüşleri 5 farklı tema altın toplanmıştır. Öğretmenler Hukuk ve adalet dersinin öğrencilerde bilinç ve farkındalık oluşturduğunu $(f=37)$, öğrencilerin sosyal becerilerine katkı sağladığını $(f=33)$, hukukla ilgili kavram ve değerleri öğrendiğini $(f=20)$, yargı sistemini tanıdığını $(f=7)$ ifade etmişlerdir. Katılımcılardan 10 tanesi ise dersin bir katkısı olmadığı yönünde görüş belirtmişlerdir.

Araştırmaya katılan öğretmenlerden "Bilinç ve Farkındalık" yönünden katkı sağladığını ifade edenler, Hukuk ve adalet dersinin Öğrencilerde hukuk ve adalet bilinci gelişimine katkı sağladığını $(f=14)$, Öğrencilerin hak ve sorumluluklarını bilmesinde etkili olduğunu $(f=13)$, öğrencilerde genel bir duyarlıık ve farkındalık sağladığını $(f=10)$ belirtmişlerdir.

Katılımcıların Hukuk ve Adalet Dersi Öğretim Programının Uygulanması Sürecinde Yaşadıkları Sorunlara iliş̧in Bulgular

Katılımcı öğretmenlerin hukuk ve adalet dersi uygulama sürecinde yaşadığı sorunlar ve çözüm önerileri tablo 10 'da yer almaktadır.

Tablo 10. Hukuk ve Adalet Dersi Öğretim Programı Uygulama Sürecinde Karşılaşılan Sorunlar

\begin{tabular}{|c|c|c|}
\hline Tema & Kategori & f \\
\hline \multirow{3}{*}{$\begin{array}{l}\text { Öğretim Programı Boyutu } \\
(\mathrm{f}=30)\end{array}$} & Kazanım ve bazı kavramlar öğrencinin seviyesinin üzerinde kalıyor & 23 \\
\hline & $\begin{array}{l}\text { Ders seçmeli olduğu için okul idareleri ve velilerce pek tercih edilmiyor, Öğrenciler önem } \\
\text { vermiyor }\end{array}$ & 5 \\
\hline & $\begin{array}{l}\text { 6. ve 7.Sınıf için aynı kitap ve programın uygulanması, hazırbulunuşluk farkı açısından sorun } \\
\text { olabiliyor. }\end{array}$ & 2 \\
\hline \multirow{6}{*}{ Uygulama Süreci ( $f=39)$} & $\begin{array}{l}\text { Ders kitabının okullara ulaşmasında sorunlar yaşanmaktadır, Öğretmen Kılavuz kitabı olma- } \\
\text { lıdır }\end{array}$ & 15 \\
\hline & Etkinlik ve görseller artırılmalıdır & 8 \\
\hline & Konuların günlük hayatla ilişkisi kurulamaması ve güncellenmemiş olması & 6 \\
\hline & Yargı kurumlarını ziyaretle ilgili gerekli işbirliği sağlanamıyor & 5 \\
\hline & Ders saatinin yetersiz olması & 3 \\
\hline & Öğretmenlerin hukuka ilişkin bilgileri yetersiz kalabiliyor & 2 \\
\hline \multirow[t]{2}{*}{$\begin{array}{l}\text { Sorun Yaşanmadı } \\
(\mathrm{f}=33)\end{array}$} & Ders işleme sürecinde bir sorunla karşılaşmadım & 33 \\
\hline & Toplam & 102 \\
\hline
\end{tabular}

Tablo 10 incelendiğinde Hukuk ve Adalet dersi öğretim programının uygulanması sürecinde yaşanılan sorunlara ilişkin soruya 102 öğretmenin yanıt verdiği görülmektedir. Öğretmenlerin verdikleri cevaplar 3 ayrı tema altında toplanmıştır. Katılımcılar öğretim programından kaynaklı bazı sorunlar yaşadıklarını $(f=30)$, uygulama sürecinde bazı sorunlar yaşadıklarını $(f=39)$ ifade etmişlerdir. 33 öğretmen ise herhangi bir sorun yaşamadığını ifade etmiştir. 
Öğretim programı boyutu ile ilgili sorun yaşadığını ifade eden öğretmenler, kazanım ve bazı kavramlar öğrencinin seviyesinin üzerinde kaldığını $(f=23)$, ders seçmeli olduğu için okul idareleri ve velilerce pek tercih edilmediğini, öğrencilerin önem vermediğini $(f=5), 6$. ve 7 .Sınıf için aynı kitap ve programın uygulanmasının hazırbulunuşluk farkı açısından sorun olabildiğini $(f=2)$ ifade etmişlerdir.

\section{Tartışma ve Sonuç}

Araştırmaya katılan öğretmenlerin kazanımlara yönelik görüşlerinin olumlu yönde olduğu belirlenmiştir. Öğretmenler, kazanımların programın temel yeterliliklerine, toplumun ve öğrencinin ihtiyaçlarına uygun, öğrenciyi hayata hazırlayacak nitelikte ve öğrencilerde hukuk ve adalet bilincinin yerleşmesini sağlayacak şekilde olduğu yönünde görüş belirtmişlerdir. Ancak kathlımcı öğretmenlerin büyük çoğunluğu, kazanımların öğrencilerin hazırbulunuşluk seviyesine uygun olup olmadığı konusunda kararsız olduklarını belirtmişlerdir.

Araştırmaya katılan öğretmenlerin içeriğe yönelik görüşlerinin olumlu yönde olduğu belirlenmiştir. Öğretmenlerin görüşleri doğrultusunda içerikteki bilgilerin öğrencilerin günlük yaşamda kullanabileceği, önemli, güncel ve aynı zamanda hukuk biliminin temel kavramlarına yönelik farkındalık yaratacak nitelikte olduğu şeklinde sonuçlara ulaşılmıştır. Değerler eğitimi açısından bakıldığında ise öğretmenler Hukuk ve Adalet dersi içeriğinin adalet (adil olma) değerinin kazandıracak nitelikte olduğunu ifade etmişlerdir.

Araştırmaya katılan öğretmenlerin öğrenme öğretme sürecine yönelik olarak kararsız oldukları yönünde bulgular elde edilmiştir. Katılımcılar, programın farklı yöntemleri uygulamaya imkân verme açısından, öğrenciyi aktif kılma açısından ve konu sonu etkinliklerinin etkililiği açısından kararsız olduklarını ifade etmişlerdir. Programın uygulanmasına yönelik açıklamalar bölümünde yer alan yöntemlerin, yargı kurumlarına ziyaretlerin gerçekleştirilmesi etkinliklerinin de yeterli düzeyde uygulanamadığı görülmektedir.

Araştırmaya katılan öğretmenlerin, programın ölçme değerlendirme boyutuna yönelik yönelik olarak kararsız oldukları yönünde bulgular elde edilmiştir. Hukuk ve Adalet dersinin öğretimi sonrası yapılan ölçme değerlendirme etkinlikleri sonrasında hedeflenen kazanımların gerçekleştirilebildiğine ilişkin sonuçlara ulaşılmışır. Öğretmenler, ders kitabındaki ölçme araçlarını ve etkinliklerdeki soruların üst düzey zihinsel becerileri ölçme becerisine ilişkin kararsız olduklarını ifade etmişlerdir. Öğretmenlerce programın ölçme değerlendirme boyutu genel olarak değerlendirildiğinde, programın ölçme değerlendirme yaklaşımının çağdaş yaklaşımlara uygunluğu ve ölçme faaliyetleri ile ilgili programdaki açıklamaların yeterliliği ile ilgili kararsız oldukları yönünde görüş belirtmişlerdir.

Araştirmaya katılan öğretmenlerin, Hukuk ve Adalet dersinin genel özelliklerine yönelik görüşlerinin olumlu yönde olduğu belirlenmiştir. Öğretmenler hukuk ve adalet dersinin okullarda her eğitim öğretim yılında seçilmesi gereken bir ders olduğu, öğretmenlerin bu ders kapsamı ile ilgili hizmet içi eğitime ihtiyaç duyduklarını belirtmişlerdir. Dersin öğrencilere katkısı açısından ise, öğretmenler öğrencilerde hukuk ve adalet bilincinin oluştuğunu gözlemlediklerini, dersi alan öğrencilerin kurallara uyma davranışında artış gözlemlediklerini ifade etmişlerdir.

Temel eğitimin birçok amacı vardır. En birinci amacı ise çocukları hayata ve bir üst eğitim kuruma hazırlamaktır. Eğitim bilişsel becerileri kazandırmanın yanında, toplumda iyi bir vatandaş, etkin vatandaş olabilmek yolunda öğrencilerin kazanması gereken beceri ve tutumları da kazandırma amacı taşır. Bireyin içinde bulunduğu topluma uyumu, doğal ve toplumsal çevreye uyumu eğitimin önemli görevlerinden biridir (Oğuz, 2013a).

Eğitim bireyin davranışlarını temel alır ve bunu istenilen hedefe yönelik olarak değiştirmeye çalışır. Bu açıdan hukuk ve eğitimin davranışları değiştirme hedefi, ortak bir yönü olarak kabul edilebilir. Eğitim bireyin davranışlarına yön verirken, hukuk bireyin davranışlarına kurallar ile yön verip toplumsal düzeni sağlamaya çalışır.

Birey toplumsal yaşamın gereği olarak kural olgusuyla yaşamı boyunca iç içedir. Birey kural ve düzen ile erken yaşlarda ailesinde ve sosyal çevresinde tanışır. Aile ve çevrenin bireye benimsettiği kurallar hukuk kuralları dışında kalan kurallardır. Ancak toplumsal düzeni daha etkili bir şekilde sağlayan hukuk kurallarının öğretimi de önem taşımaktadır. Bu noktada bu alandaki derslere önemli görevler düşmektedir. Geleceğin büyükleri olan çocuklara hukuk ve adalet bilincini kazandırmak toplumsal düzenin geleceği için gereklidir.

Hukuk bireylerin toplumsal ilişkilerinde düzen sağlamak, bu düzeni sağlarken adalet, eşitlik, saygı gibi değerlerinde toplumda içselleştirilmesini sağlamak amacındadır. Ortaokul Hukuk ve Adalet dersi öğretim programındaki amaçlar ve yetkinliklerde hukukun bu en temel amacına hizmet etme amacı taşır. Hukuk ve adalet dersi bireylere sadece hukuki bilgi ve becerilerin kazandırılması değil, bu becerilerin günlük yaşamla ilişkilendirilerek toplumsal düzenin geleceğini

| Kastamonu Eğitim Dergisi, 27(4), 2019| 
de teminat altna almayı hedefler. Toplumsal roller açısından öğrenci rolünde olan birey hukuka ilişkin temel kavram ve becerileri, okul ortamında öğrenerek yaşamının bir parçası haline getirebilirse, toplumsal hukuk ve adalet bilinci yerleşecek ve toplumsal ilişkilerde uyuşmazlıklar olabildiğinde az yaşanacaktır.

Araştırma kapsamında öğretmen görüşlerinden elde edilen sonuçlar, hukuk ve adalet dersinin öğrencileri açısından faydalı olduğu, hukuk, adalet, hak, sorumluluk bilincinin yerleşmesine katkı sağladığını ortaya koymaktadır. Hukuk ve Adalet dersi hem eğitsel hem de hukuki sistem açısından katkı sağlamaktadır.

Oğuz (2013a) tarafindan yapılan araştırmada, 8.sınıf öğrencilerinin hukuk okuryazarlığı düzeylerini ölçmek amaçlanmış ve 8.sınıf öğrencilerinin hukuk okuryazarlığı düzeyinin belirlenen değerlere göre yüksek çıktığı belirlenmiştir. Alıcı (2013) tarafindan yapılan araştrmada, Hukuk ve Adalet dersinin öğrencilerde hukuk bilincini geliştirmeye etkisi incelenmiş, uygulanan hukuk davranış ölçeğinde tüm algılarda yükseliş görülmüş, hukuk ve adalet dersinin hukuk davranış algılarını yükselttiği tespit edilmiştir.

Kara ve Tangülü (2017) tarafinda yapılan araştırmada sosyal bilgiler öğretim programında hukuk ve politik okuryazarlık kazanımlarına ilişkin bir durum çalışması gerçekleştirilmiştir, sosyal bilgiler dersinin söz konusu okuryazarlık alanlarına önemli ölçüde katkı sağlar nitelikte kazanımlara sahip olduğu, etkin vatandaşlık davranışının gelişiminin hukuk okuryazarlığı ve politik okuryazarlık seviyesinin yüksek olması ile ilişkili olduğu ifade edilmiștir. Ünlütepe (2016) tarafindan yapılan araştrmada temel ve ortaöğretim kurumlarında hukuk eğitimi verilmesi gerekliliği ve buna ilişkin sebepler ve çözüm önerileri sunabilmek amaçlanmış, araştırma sonuçları çerçevesinde, hukuka uygun davranıs modelinin erken yaşlarda benimsenmesi ve bu şekilde hukukilik bilincinin sağlanması ile hukuka güvenin oluşturulmasında Hukuk ve Adalet dersinin önemli payının olduğu vurgulanmıştır.

Gülener (2013) tarafinda yapılan araştırmada, çocuklarda etik anlayışının, eleştirel düşüncenin ve vatandaşlık bilincinin gelişmeye başladığı dönemler olan ortaokul düzeyinde hukuk ve adalet dersinin verilmesinin, hukuk, adalet, insan hakları gibi kavramların toplumsal düzeyde benimsenmesini kolaylaştııı etkide bulunacağı ifade edilmiştir.

Çengelci (2017) tarafindan yapılan araştırmada öğrencilerde hukuk ve adalet bilincini geliştirmeyi amaçlayan Hukuk ve Adalet dersi öğretim programı ve öğretim materyalinde hangi değerlere yer verildiği incelenmiş, Hukuk ve Adalet öğretim programında adalet, sorumluluk, eşitlik, saygı, cesaret, duyarlılık, barış ve uzlaşma ile güven değerlerine yer verildiği görülmüştür. Hukuk ve Adalet dersi öğretim materyalinde ise adalet, sorumluluk, güven, saygı, özgürlük, eşitlik, yardımlaşma, dayanışma, sevgi, ölçülü olma, doğal çevreye duyarlıık ile barış değerlerine yer verildiği belirlenmiştir.

Alanyazındaki kuramsal ve uygulamalı araştrrmalar incelendiğinde, hukuk ve adalet dersinin öğrencilere hukuk ve adalet bilinci yönüyle katkılar sağladığı, dersin hukukun toplumsal düzeni sağlama amacına hizmet ettiğine, toplum açısından önemli birçok değeri kazandırmaya yönelik içerikleri olduğuna yönelik sonuçlara ulaşıldığı görülmektedir.

Araştırmamız kapsamında öğretmen görüşlerinden elde edilen sonuçlara bakıldığında dersin hukuk ve adalet bilinci sağladığı, kurallara uyma davranışında artış yaşandığı, öğrendiklerini günlük yaşantılarına yansıttı̆ı, hukuka ilişkin temel kavramlara ilişkin farkındalık oluştuğu, değerler eğitimi kapsamında öğretim programlarında yer alan değerlerin kazandırımasında etkili olduğu şeklinde sonuçlara ulaşılmıştır. Alanyazındaki araştırma sonuçları ve araştırma kapsamındaki sonuçlar karşılaştııldığında sonuçların benzerlik taşıdığı, birbiriyle örtüştüğü görülmektedir

\section{5. Öneriler}

- Hukuk ve Adalet dersi 2013 öğretim programına ilişkin güncelleme çalışmalarında öğrencilerin sınıf seviyesi göz önüne alınarak kazanımlarda, kavramlarda düzenlemeler yapılabilir.

- Konu içeriklerine, güncel hayatla ilişkili, öğrencilerin ilgisine ve ihtiyacına yönelik olarak konular eklenebilir. Bu noktada özellikle okul kurallarına da özel bir konu başlığı açılarak bu kurallar hakkında gerekli bilgilendirme yapılmalıdır.

- Değerler eğitimi bağlamında hukuk ve adaletle ilişkili değerlere ağırlık verilmelidir. Adalet, eşitlik, haklara saygının sadece hukuki bir kavram olmaktan ziyade evrensel insani değerler içinde yer aldığı vurgulanabilir.

- Hukuk ve Adalet dersi 7. ve 8.sınıf seviyesinde zorunlu ders olarak okutulmalıdır.

- Hukuk ve Adalet dersine ilişkin öğrenci algı ve görüşlerini inceleyen farklı araştırmalar yapılabilir.

- Hukuk ve Adalet dersine yönelik olarak ders kitabına ek olarak dijital ve basılı materyaller geliştirilmelidir. 


\section{Kaynakça}

Alıcı (2013). Ortaokullarda Okutulan “Hukuk ve Adalet” Dersinin Öğrenciler Üzerinde Hukuka Yönelik Duyuşsal Eğilimler Algısına Etkisi. The Journal Of Europe-Middle East Social Science Studies, s:107-131

Anayurt, Ö. (2011). Hukuka Giriş ve Hukukun Temel Kavramları. Ankara: Seçkin.

Andaç, F. (2008). Hukukun Temel Kavramları. Ankara: Detay.

Ay, E. (2014). Karakter Eğitiminde Vatandaşlık Eğitiminin Yeri ve Önemi. R. Turan, \& K. Ulusoy içinde, Farklı Yönleriyle Değerler Eğitimi (s. 212-222). Ankara: Pegem Akademi.

Aral, V. (1985). Hukuk ve Hukuk Bilimi Üzerine. İstanbul: Filiz.

Bilge, N. (2010). Hukuk Başlangıcı: Hukukun Temel Kavram ve Kurumları. Ankara: Turhan Kitabevi.

Büyüköztürk, Ş., Kılıç Çakmak, E., Akgün, Ö. E., Karadeniz, Ş., \& Demirel, F. (2012). Bilimsel Araştırma Yöntemleri. Ankara: Pegem Akademi.

Cansel, E., \& Özel, Ç. (2012). Hukuk Başlangıcı. Ankara: Tuna Matbaacılık.

Çengelci Köse, T. (2017, Ağustos). Hukuk ve Adalet Dersi Öğretim Programı ve Öğretim Materyelinde Değerler. Uluslararası Sosyal Araştirmalar Dergisi, s. 656-664.

Güriz, A. (2003). Hukuk Başlangıcı. Ankara: Siyasal Yayınevi.

Gülener, S. (2013). Türkiye'de Hukuk ve Adalet Bilincinin Geliştirilmesine Yönelik Önemli Bir Adım: Hukuk ve Adalet Dersi. Güncel Hukuk.

Ildır, G. (2006). Hukuka Giriş. Ankara: Nobel.

Karasar, N. (2014). Bilimsel Araştırma Yöntemleri. Ankara: Nobel.

Kara ve Tangülü (2017). Sosyal Bilgiler Öğretim Programında Hukuk ve Politik Okuryazarlığı Üzerine Bir Durum İncelemesi. Araştırma ve Deneyim Dergisi, 2 (1), 1-28. Retrieved from

MEB. (2013). Ortaokul ve Imam Hatip Ortaokulu Seçmeli Hukuk ve Adalet Dersi Öğretim Programı. Ankara: Milli Eğitim Bakanlığı Talim ve Terbiye Kurulu Başkanlığı.

MEB, (2017). 17.09.2017 tarih ve 1701351279 sayılı BiMER başvurusuna ilişkin Milli Eğitim Bakanlığı İstatistik ve Performans Daire Başkanlığı'nın 06.10.2017 tarihli cevabi yazısı.

Patil, S., \& Lavanya, C. (2012, Ağustos). A Study On Legal Literacy Among Secondary School Students. Indian Streams Research Journal.

Oğuz, S (2013 a). Ortaokul Öğrencilerinin Sosyal Bilgiler Eğitimi Çerçevesinde Hukuk Okur-yazarlık Düzeylerinin Belirlenmesi. Yayımlanmamış Doktora Tezi. Gazi Üniversitesi Eğitim Bilimleri Enstitüsü

Oğuz, S. (2013 b). Hukuk Okuryazarlığı. E. Gençtürk, \& K. Karatekin içinde, Sosyal Bilgiler İçin Çoklu Okuryazarlıklar (s. 160-175). Ankara: Pegem Akademi.

Ulusoy, K., \& Dilmaç, B. (2014). Değerler Eğitimi. Ankara: Pegem Akademi.

Ünlütepe, M. (2016). Temel ve Ortaöğretim Okullarında Hukuk Eğitimi Üzerine. Legal Hukuk Dergisi.

Yıldırım, A., \& Şimşek, H. (2013). Sosyal Bilimlerde Nitel Araştırma Yöntemleri. Ankara: Seçkin Yayınları.

Zariski, A. (2017, 8 20). Legal LiteracyAn Introduction to Legal Studies. www.aupress.ca: http://www.aupress.ca/index.php/ books/120240 10.08.2018 tarihinde adresinden alınmıştır 